Österreichische Akademie der Wissenschaften / Austrian Academy of Sciences AAS WORKING PAPERS IN SOCIAL ANTHROPOLOGY Volume 10

Ugo Fabietti The "Discourse" of Baluchi Nationalism and its Relations to the Idea of a Baluchi "Identity"

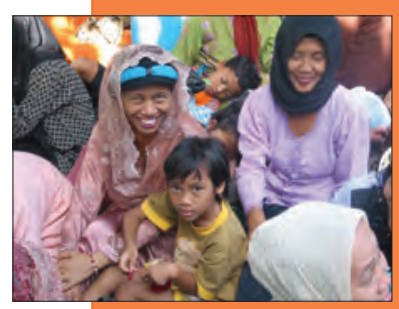

Band 10
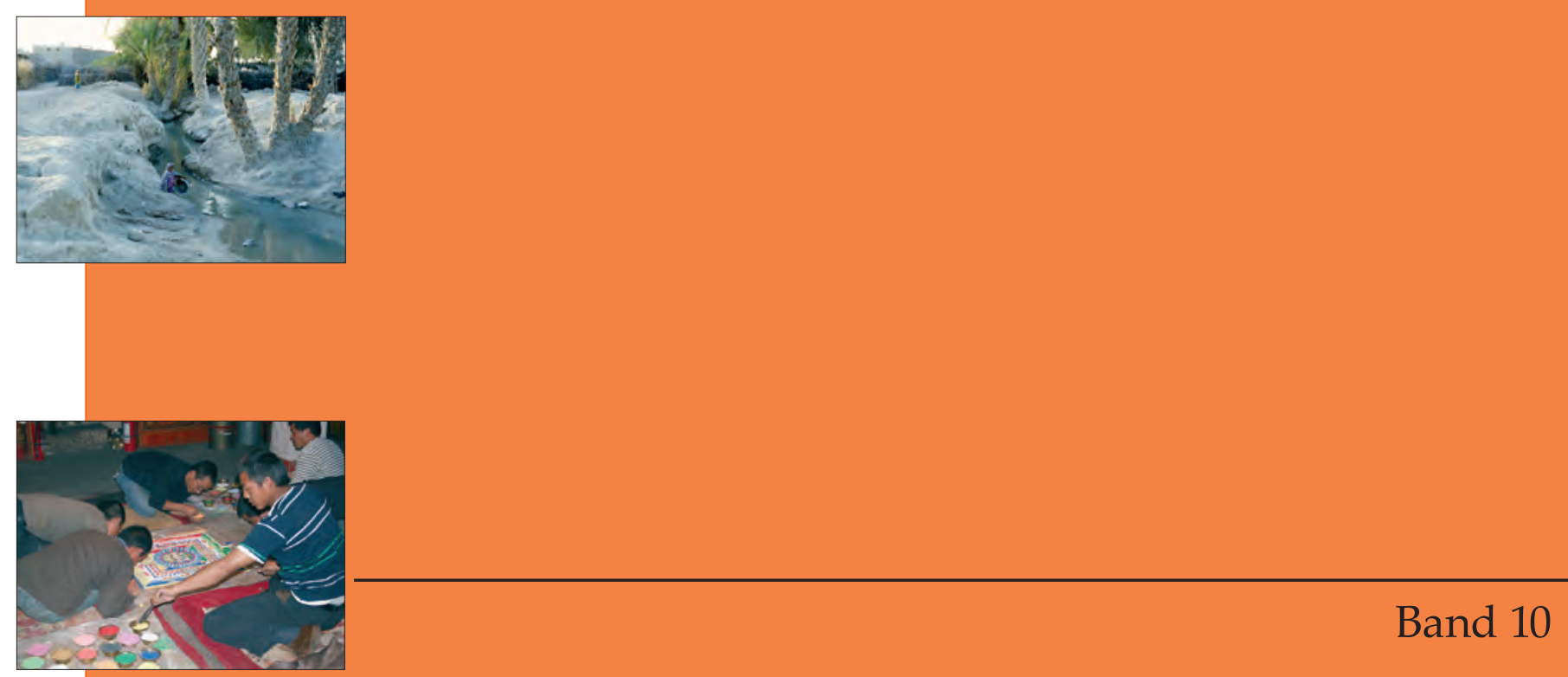


\section{AAS Working Papers in Social Anthropology / \\ ÖAW Arbeitspapiere zur Sozialanthropologie}

ISSN: 1998-507X

doi: 10.1553/wpsa10

ISBN: 978-3-7001-6699-3

Wien 2009

\section{Editors / Herausgeber:}

Andre Gingrich \& Guntram Hazod

(C) Institut für Sozialanthropologie

Zentrum Asienwissenschaften und Sozialanthropologie

Österreichische Akademie der Wissenschaften

Prinz-Eugen-Straße 8-10

A-1040 Wien

Fax: 01/ 51581-6450

E-Mail: sozialanthropologie@oeaw.ac.at 


\title{
THE “DISCOURSE” OF BALUCHI NATIONALISM AND ITS RELATIONS TO THE IDEA OF A BALUCHI "IDENTITY"
}

\author{
UGO FABIETTI \\ University of Milano Bicocca
}

\section{Nationalism, anthropology and history*}

In the last quarter of the twentieth century the theme of identity, stated chiefly in terms of ethnicity, received particular attention both from anthropologists and historians. In many cases that common attention was coupled with an interest in the reappearance of nationalism which, as a phenomenon by then considered obsolete in its "classic" form, had begun to assume planetwide dimensions (Gingrich and Banks 2006). Since it had not spared even the "old Europe" (where it had been believed dead and buried), and due to its appearance in places where it was thought that it could not still, or no longer, manifest itself, ${ }^{1}$ this phenomenon led to a convergence of interests on the part of historians and anthropologists.

History and anthropology thus found themselves examining the same phenomenon from very close points of view: history being enriched by the influences of anthropology (the comparative aspect) and vice versa (attention to the West). Hence important works of synthesis produced in the last part of the twentieth century and now regarded as classics in each of the two fields, bear evident signs of the other discipline (Armstrong 1982; Anderson 1983; Gellner 1983; Smith 1986, etc.). Anthropologists and historians agree that nationalism, as an ideological construct and political movement, must be treated as a relatively recent phenomenon with substantially "Western" roots. Whilst however some, like Anderson and Gellner, regard as irrelevant the idea that it may be linked to a pre-existent identity sentiment, others, like Armstrong and Smith, claim instead that nationalism is the product of a pre-existent "feeling" of identity. In this case the question therefore would be to ascertain whether cultural elements exist which, in certain circumstances, may engender collective movements and forms of identity defined as "nationalisms".

Supporters of the first perspective maintain that only precise historical circumstances to be found in the modern West favoured the emerging idea of a "national" identity. Upholders of the second perspective believe on the other hand that recent and current nationalisms are the result, in their dynamics and symbolic references, of previous identity forms. The most convinced supporter of this second perspective is Anthony D. Smith. In what is by now a classic work, The Ethnic Origins of Nations (1986), he proposed, for the purpose "of retracing the foundations and ethnic roots of modern nations", a systematic examination of "cultural forms, sentiments, attitudes and perceptions to the degree in which they are expressed and codified in myths, memories, values and symbols" (Smith 1986: 53-4).

\footnotetext{
* This article is based on a paper held by the author in the framework of the ISA (Institute for Social Anthropology) International Guest Lecture Series at the Institute for Social Anthropology of the Austrian Academy of Sciences, Vienna, June 3, 2009.

${ }^{1}$ The two options naturally depend on clearly different, but both linear views, of history.
} 
For my part, I shall attempt to develop the theme of the connections between nationalism and ethnic identity, in relation to a relatively recent phenomenon like that of "Baluchi nationalism".

By the very fact of establishing that connection, I therefore accept Smith's general indication. My intent however is not exactly to develop an "archaeological" perspective on Baluchi nationalism in an attempt to spot common values and symbols rooted in a pre-existent "ethnic identity". Rather, my purpose would be to highlight the logic of the nationalist "discourse", as developed in Baluchistan in the second half of the twentieth century. By "discourse" I mean (in line with Foucault 1969) a number of enunciations, representations, images and symbols that tend to produce coherencies of meaning. And which thereby tend to mould (shape) the objects they refer to. The "discourse" which I propose to consider is not therefore only the explicit discourse of nationalists, consisting of programmatic statements, political appeals and verbal as well as written theorisations; it is also the discourse which consists of opinions, declarations and feelings, expressed by individuals not directly engaged in politics but who, albeit only broadly, share the sentiments of the nationalists. The "discourse of Baluchi nationalism" is in fact a "field" of resistance, debate and action fuelled by whatever it considers useful in creating an image of the Baluch as a people with a common origin, culture and history.

Baluchi nationalism is a political, ideological and intellectual movement which arose within one of the largest "stateless nations" in South West Asia (estimates of the number of Baluchi speakers oscillate between 18 and 25 million, including migrants working in the Gulf countries and Africa). The idea of Baluchistan as a "nation" was probably first mooted in an article published in 1933 in the Karachi weekly Al Baluch, the official organ of the Anjuman-e Ittihad-e Baluchistan (Organisation for the Unity of Baluchistan). According to that article, "Greater Baluchistan" (as it is called even today by the nationalists) should have included (see the map below) in addition to Iranian Baluchistan and Indian (now Pakistani) Baluchistan, the Sindh, the Bahawalpur region and Dera Ghaza Khan and Ismail Khan areas, considered the point of maximum expansion northwards by the Baluchi during the sixteenth century (Inayatullah 1987: 31-32). The idea of a "Greater

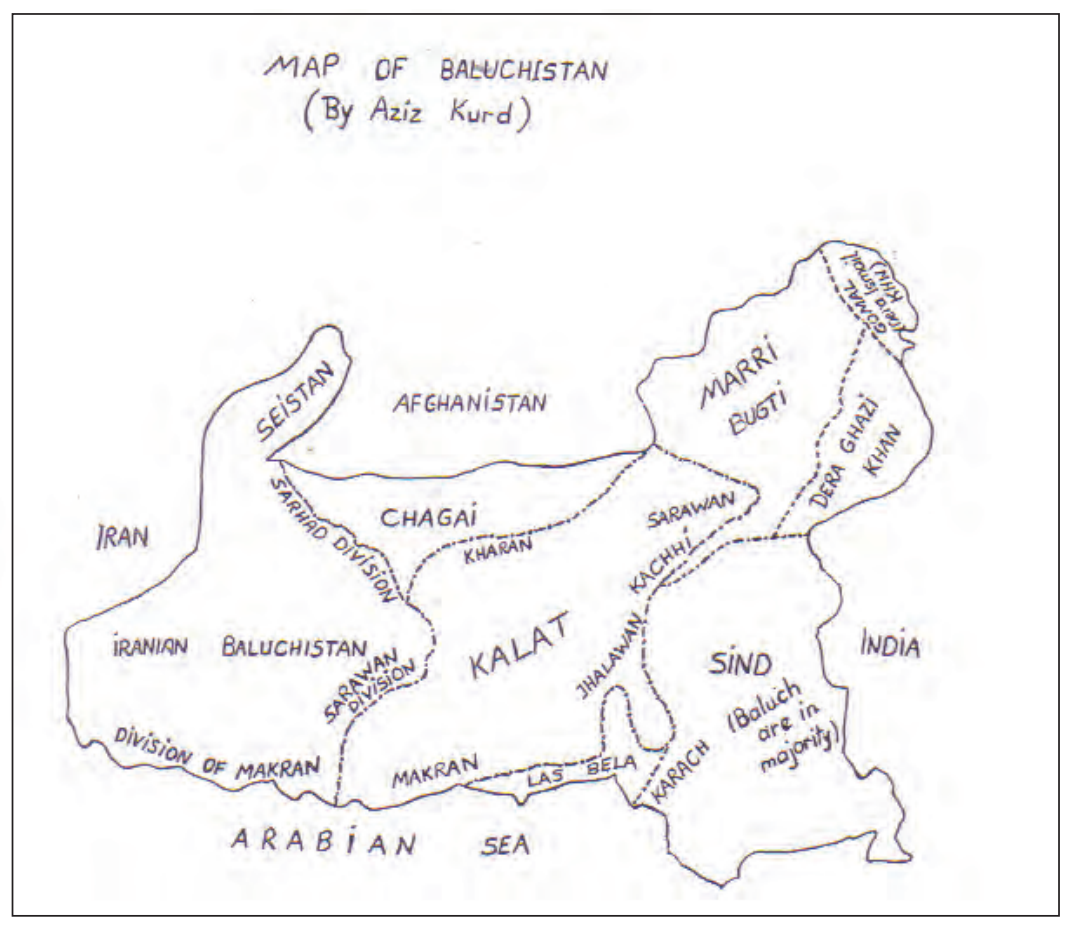

Fig. 1:

The first map of "Greater Baluchistan" by Mir Abdul Aziz Kurd, the General Secretary of the Anjuman-e Ittihad-e Balochistan (From Inayatullah 1987). 
Baluchistan" was one of the many projects formulated by those who, between 1920 and 1930 , had been trying to picture the future of the Indian Subcontinent after a hypothetical departure by the British. The 1930s projects had no sequel, due to the intervention of the British intelligence who silenced the nationalists, and, after the partition of 1947, to the annexation (in two stages) of Baluchistan by the new state of Pakistan. The nationalistic spirit survived however in the decades that followed, to regain fresh impetus in the seventies.

\section{Memory-archive and memory-function: the Baluchi nationalism and its themes.}

Baluchi nationalism raised its head, therefore, and developed as a political sentiment and movement, in response to the presence first of the British, and later of the Pakistanis in the region. As an intellectual and ideological movement, it resulted from the merging of local identity memories and ideas that had arrived with colonial rule. Also among the ideas brought with colonial dominion, in addition to those connected with the nation-state as developed in Europe during the modern age, were those filtered through the works of western authors (mainly British) interested in Baluchi history and, more generally, in the history of the populations of the Anglo-Indian empire and its bordering regions.

The distinction between local identity memories and imported ideas is useful. Because, whilst it is true, as Ernest Gellner maintains, that it is nationalism that makes the nation and not the other way round, it is also true that the nationalist issue always refers to values, models, stories, world-views and social practices existing prior to nationalism.

All these elements existing prior to nationalism consist of symbols and behaviours which enable subjects to perceive themselves, by ascription, as belonging to one and the same "group" (Barth 1969).

But these values, models, stories, etc, are not always simultaneously active. Indeed, many of them are, so to speak, "dormant" - or to use an expression by Aleida Assmann, stored in what she herself calls the "memory-archive". In her book Erinnerungsräume, Aleida Assmann in fact called an "amorphous mass" the accumulated unorganised memories which can be "used" only if taken into consideration by a "memory-function" that "retrieves" and bends them, so to speak, to its own purpose (Assmann 1999).

So we could say that the discourse of Baluchi nationalism is founded on a form of memory-function, which takes elements of the memory-archive and organises them according to a purpose. This perspective has the advantage, over Anthony Smith's idea, of not having to connect in a necessary and organic way the nationalistic sentiment with what he calls "cultural forms, sentiments, attitudes and perceptions expressed and coded in myths, memories, values and symbols", that is to say, in already organised discourses.

Within the memory-function, these ideas, values and behaviours "retrieved" from the memoryarchive interact with other elements which, as I was saying, Baluchi nationalism had absorbed during and after the colonial era: the idea of a nation, as developed in Europe in the modern age, and the theories of western authors interested in the history of the Baluch and of the peoples of the Anglo-Indian empire.

Playing on the interconnection between these elements arising from the memory-archive and ideas more or less recently imported, nationalism organises its memory function in such a way as to bestow coherency on its discourse, and fresh meanings which are the peculiarity of its reasoning. 
In order to make things less abstract, I shall try to show how the memory-archive elements come into the discourse of Baluchi nationalism. For its part, this discourse is organised in relation to ideas of a European origin and as a result of moulding-shaping, as Foucault says, a new "object of reflection": the legitimacy of Baluchistan as a possible nation-state.

In a very general sense, it can be said that the Baluchi nationalists seek to legitimate their claims by referring chiefly to the following points:

a) both the popular and the cultivated idea that the Baluch have of their own past history: a theme closely linked to the question of

b) the ethnogenesis of the Baluch people

c) the territorial question and, to a lesser extent, to the

d) religious factor.

\section{Origins}

Although the Baluch speak a language of "Indo-European" family related to Farsi (Persian), their roots are traced back, traditionally, to Mir Hamza, paternal uncle of the Prophet Muhammad. The reference to this mythic ancestor, chosen probably as such at the time of the Islamization of Baluchistan by the Arabs (in the eleventh century of the Christian era), therefore sets the origins of the Baluch people at the dawn of Islam. The poems and legends passed down orally ${ }^{2}$ tell, in effect, a story of conquerors originating from the north west. These would appear in fact to have initiated the occupation of the area today called Baluchistan in the eleventh century, which was then completed during the fifteenth century under the leadership of the legendary "national" hero Mir Chakar Rind. In the course of the fifteenth and sixteenth centuries, part of the Sindh and of the Punjab fell, in effect, under the influence of Baluchi chiefdoms, thereby boosting the nationalist image of a "Greater Baluchistan". This is an example of how the memory-archive was exploited to foster, in the vision of the early nationalists, the idea of a country whose borders would extend beyond those recognised today. ${ }^{3}$

Imagining Baluchistan as a region inhabited by peoples whose ancestors came from an area situated between Mesopotamia and the region south of the Caspian Sea, today's theorists of the Baluchi nation restate the idea of a conquest, or migration, which is not rare in social cosmologies seeking to explain both the origin of a people and rule by one group over others.

The idea of the ethnogenesis of the Baluch tends in fact to reassert both cultural unity and common geographic origin.

This idea of population by groups originating from the west is confirmed, in the eyes of cultivated nationalists, by the works of western orientalists who, at the end of the nineteenth century tended to present the origins of the Baluchi people in a "migratory" perspective (Janmahmad 1988: 17, 25; Inayattullah 1987: 33).

In their turn, however, these orientalists based their hypotheses on popular Baluchi tradition itself, and in particular on oral poetry, which began to be translated into western languages towards

\footnotetext{
${ }^{2}$ Baluchi language received significant contributions in lexical, and phonetic terms, from Farsi, Arabic, Pashtu and Urdu. The first attempts at transcription date from the beginning of the $20^{\text {th }}$ century through the use of the Arab alphabet suitably adjusted to Baluchi phonetics (cf. Sardar Khan Baloch 1977).

${ }^{3}$ Baluchi territory extends between Iran, Pakistan and, to a lesser degree, Afghanistan.
} 
the middle of the nineteenth century (Dames 1904, 1907). The "migratory thesis" was a product of the historical perspective which in the meantime had developed in the West on the strength of comparative studies of Indo-European languages (Dames 1904: xiii). That perspective consisted essentially in an idea of how these languages spread as a result of the "fragmentation" of a ProtoIndo-European society, culture and language into derived and interrelated societies, cultures and languages (Renfrew 1987).

But it is not only from these cross-references between one tradition and another that cultivated nationalism gets what it needs to "invent" a tradition, at least in the sense in which the term "invention" is understood by Hobsbawm and Ranger in their classic study of "tradition" (1983). A sort of local "sociology" (deposited in the "memory-archive") also contributes to its endorsement.

As an example, I recall that during the period of my researches in the south of the country, the morphological characteristics of Baluchi society were seen as a proof of past migrations.

In southern Baluchistan (where the social structure differs, as I shall explain better later on, from that of the north), numerous patronymic groups (for the most part endogamous), are present. At a purely representational level, these are the backbone of local society.

These groups (zât) are not concentrated, but scattered very widely across the territory. An analysis of ethnographic data tends to suggest that this dispersion may be related to extremely fluid residential patterns, which are in their turn a consequence of the local landed estate structure and its management.

Although the principal sources of sustenance of the local populations have by now for quite a while been the remittances of emigrants working in the Gulf region and in the big cities of eastern Pakistan, besides those of commerce, smuggling and heroin trafficking (Akbar 1989), agriculture has left on this part of the country an imprint of "longue durée" (to use Fernand Braudel's expression). And this has substantially helped to shape the local social morphology.

Southern Baluchistan is a semi-desert region, crossed by semi-permanent waterways (kaur) along which prevails the cultivation of date palms and cereals. This cultivation is achieved by means of irrigation. The water from each channel (kariz) is divided among a certain number of owners holding hour-quotas (or sub-factions of an hour). At any time the various quotas can be alienated, purchased, inherited, leased or transferred by way of bridewealth or dowry (Fabietti 1996a). This means that not infrequently an individual may find himself possessing, or at any rate managing, water quotas of different amounts and in different channels which may even be far apart. The residential patterns adopted tend, in this situation, to depend on options and choices that are in their turn influenced by manifold factors. The latter may consist in the quality and location of crops; in the water quotas possessed in varying measures and in different oases, and in the location and quantities of those which an individual may gradually come to possess (by inheritance, purchase, marriage, etc.). These, and important factors such as the distance between fields, the type of agreement reached with other owners, and a variety of considerations, may all combine to influence the choice of residence by a person (Pastner 1972).

Many individuals involved in agricultural activities share this interpretation relative to the dispersion of patronymic groups across the territory. But often, if further prompted to reflect on this morphological characteristic of their society, they tend to interpret the dispersion of patronymic groups also as a consequence of the past invasion. 
In fact, according to this interpretation, the dispersion of patronymic groups is the product of a steady shifting of the various kin groups from west to east. As they advanced they broke up, leaving behind them small groups, families and individuals who eventually formed the nuclei of a demographic growth of different patronymic groups at local levels.

To what extent this interpretation may correspond, in today's political and ideological climate, to the need to supply a "historically" and "sociologically" coherent picture of the present situation is hard to say. Certainly however, this view of the past clings to the idea of a common origin which suffuses the nationalist discourse even in its less radical versions (Inayatullah 1987: 35). What, though, this discourse "forgets" is the diversity of origins, both cultural and linguistic, claimed by the various groups of which the Baluch people (qowm) are "composed". That diversity is in fact referred to whenever it is no longer a matter of negotiating identity with external agents such as might be the Pakistani state or the international media, but within the context of local politics. In the latter case the superior status of some patronymic groups over others is still decisive (Fabietti 1992). Especially in the south of the country, which is more exposed to the influences of lands beyond the Arabian Sea, some high status groups claim, for example, relatively recent non-Baluchi origins: Arab, Persian, Indian. In the present "independentist" climate, such claims would seem to suggest an explanation of social superiority enjoyed in the past. Nevertheless even today, these distinctions often have an effective socio-political bearing on situations. The fact is that both the idea of a common origin, and that of a different origin of the various patronymic groups, in reality project two opposite and alternative images. And in an indirect but decisive way, they inform the political dialectic of today's Baluchi society. These opposite ideas, whilst not excluding each other, are referred to according to whether it is intended to assert the principles of equality, or those of hierarchy and status, as the ideal criteria for regulating social relations. ${ }^{4}$

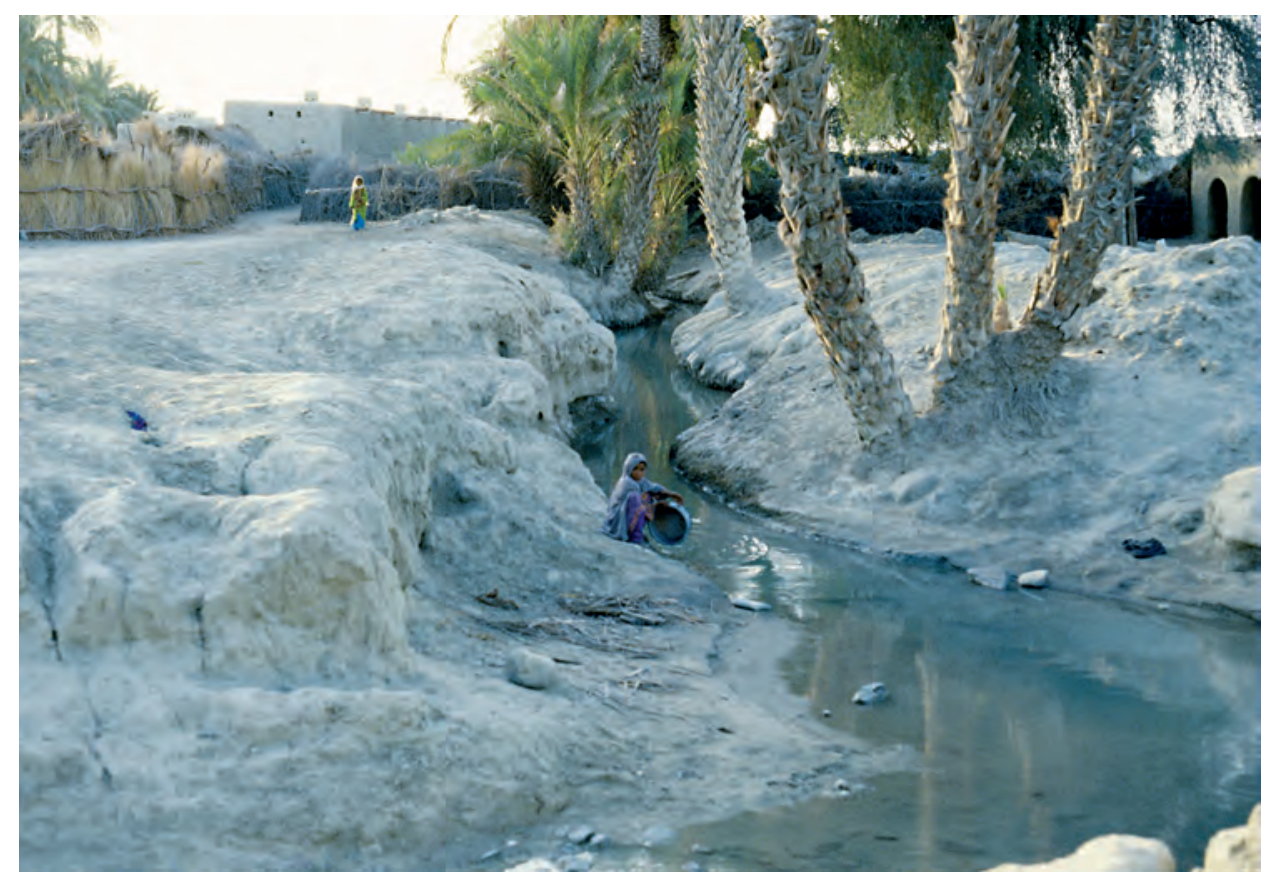

Fig. 2:

A village scene in Makran (southern Baluchistan).

\footnotetext{
${ }^{4}$ As I have tried to show elsewhere (Fabietti 1996b), the Baluchi community, especially in the south of the country, seemed torn, in the 1990s, by a profound contradiction between the two ideals on which it had long been founded, and which could have been translated respectively with the terms equality and hierarchy. The equalitarian image springs from the adhesion to certain models of behaviour which are
} 
As will be noted, the nationalist issue makes reference to the past by combining an epic passed down orally, with a number of historico-linguistic-cultural theories of western origins, and local stories about the origins of the groups which today make up the Baluchi "people".

\section{Unity}

But if the medieval epic, with its hero Mir Chakar Rind, the protagonist of poems and ballads (Sardar Khan Baloch 1977) contains "mythic" elements, the reference to a recent past assumes a more concrete meaning that can arouse more immediate reactions.

One such case is that of the vicissitudes of the Khanate of Kalat, which was finally abolished in 1955 , when it ceased to exist officially as a semi-autonomous entity and became annexed to the state of Pakistan.

The question of the Khanate is not only a thorn in the side of the nationalists, but also an essential point of reference when affirming the recent and historically well-documented existence of a political power capable, say the nationalists themselves, of unifying ex Anglo-Indian and now Pakistani Baluchistan.

The question of the status of the Khanate relative to the British is of great importance to the nationalists.

The Khanate reached the acme of its expansion in the eighteenth century, but lost its autonomy under the British policy of indirect rule. However, its position vis-à-vis the British was different to that of many other kingdoms or chiefdoms encapsulated by the Anglo-Indian empire.

Like all the other "principalities" under British dominion and ruled by Hindu (raja) or Muslim sovereigns (nawab), the proto-state of Kalat, led by a khan with autocratic powers, had stipulated a treaty with the British Crown. This (according to nationalists' opinion) allowed it to maintain its own - albeit nominal - condition as an "independent and sovereign state". The newborn Pakistan, however, ignored this detail. Deeming itself to be the legitimate heir to that part of the subcontinent which fell to its lot after the withdrawal of Great Britain, it saw fit to extend its sovereignty over all the ex-principalities of the region, including the Khanate of Kalat. In 1955, under various types of pressure, both diplomatic and military, Kalat was finally absorbed into Pakistan (Harrison 1981; Redaelli 1996).

Kalat was a long way from being a centralized state. The khan himself was an autocrat within his tribe, but not in a position to impose his will on the chieftains of other tribes that were part of a kind of confederation (Swidler 1979). Nationalists on the other hand tend to exalt the khan's function, as if this personage had been nothing less than a head of state. In its efforts to assert the politically

in their turn founded on shared values. Adult men consider themselves to belong to an "equal" community, since they are expected, regardless of their status or occupation, to conform to values perceived as something concretely attainable on a level of individual behaviour. This equalitarian image of society rests on a definition of the individual as a "moral" person. But in Baluchi society economic and political relationships are not founded on the free choice of "morally equal" individuals. Even though in decline, or being reformulated due to the effect of the new dynamics caused by the gradual insertion of the region into the framework of Pakistani political and economic life, it is the structure of the master-client relationship that dominates in terms of social dynamics. The master-client relatinship was founded, at least ideally, on the differences of status between individuals belonging to different patronymic groups. Now it is not infrequent that these differences of status are dated back to the foreign origins of the dominant groups, which origins are, in this region, synonymous with the "conquering race". 
compact character of east Baluchistan under the Khanate, the nationalist argument forgets that the loyalty of tribes to Kalat was sporadic and sometimes obtained by force. To affirm the culturally homogeneous character of the region, the nationalist argument furthermore interprets in its own way the linguistic data, whereby the Kalat region had long been considered inhabited by populations of origins different to those of the Baluch (Ahmad Yar Khan Baloch 1975; Janmahmad 1988: 162-165). The view that the Khanate of Kalat offers a precedent of political autonomy achieved by the Baluch in fact comes up against a fairly big problem. It is well known that the Khanate developed in the centre of a Brahui linguistic area. The Brahui, according to linguists, is a language closely related to the Dravidian dialects spoken by groups which, according to the "migratory" theory of Indo-European peoples, were driven by the latter towards southern India. According to this theory Brahui, spoken to this day in the Kalat region, would be the language of a Dravidian group which in the course of time mingled with neighbouring groups, assimilating their customs and institutions (Bray 1977).

In Baluchistan the Brahuiphones are concentrated exclusively in the region of Kalat, in what is for the nationalists the cradle of the first historic instance of political unity in Baluchistan. Consideration of the Khanate of Kalat as a precedent of achieved political autonomy clashes, therefore, with a considerable problem, that of a "contradictory" historical and linguistic non-homogeneity between Baluch and Brahui, between "conquerors" (the Baluch) and "dominators of the conquerors" (the Brahui). The questions of the political unity of Baluchistan and that of its cultural homogeneity are in fact, in the nationalist perspective, closely connected.

In effect, the culture of Brahuiphones is not distinguished from that of the Baluchi groups any more than the regional differences existing between the latter. Brahui itself, for the matter, was influenced by Baluchi, Pashtu and Urdu, in the same manner in which Baluchi was influenced by these idioms. Brahuiphones are as a rule bilingual and there is nothing, aside from the language used in everyday communication, to distinguish them from other Baluch.

Besides, they speak Baluchi fluently and declare themselves to be Baluch. They do not even seem to have an ethnic "dual identity" which might be displayed according to context (Barth 1969). The Brahui are perceived and perceive themselves as_Baluch.

However, for the nationalists this factual identity of Brahui-speaking groups is not sufficient. In their opinion the origins of those speaking the language of the region must comply to the historical role of the Kahnate of Kalat. In other words, it must be possible to attribute an origin (and not so much a culture) to the Brahuiphone valid enough to put them on the same plane as the Baluch.

Not convinced by the theory of European linguists (who postulated the existence of a Dravidian residual linguistic island), nor even by those of the Brahui themselves (who consider themselves Baluch to all effects), the nationalists attribute to the groups of the Kalat region a different identity but a common origin._In a perspective of this sort, the Brahui would in fact be neither the descendants of a Dravidian population, nor of an autochthonous group, but of groups with origins similar to those of the Baluch, and who arrived in the Kalat region during the same period as that of the largescale Baluchi migrations.

This is explicit in those nationalist authors who strive to assert the contemporary nature of the Baluchi and Brahui migrations, attributing the character of a historical "proof" to the myth of the origin of both peoples: if the Baluch are descendants of Mir Hamza who originated from the Arab Peninsula, the Brahui are the descendants of a certain Braho, or Ibrahim, originating from Aleppo and companions in arms and faith of the former (Janmahmad 1988). 
So for the nationalist argument, the elements legitimating the unifying role of the Khanate of Kalat lie in the common origins of the Brahuiphone and of the Baluch, and thus in terms of a common historical destiny. This began, once again, with the migration of conquering peoples from the west towards the east and was achieved in historical times with the unification of a great part of Baluchistan under the Khanate.

Linguistic difference thus becomes an altogether secondary and almost insignificant element. For it is, so to speak, reabsorbed and erased in a common original history.

\section{5. "Politologists in a balloon"}

The "cultured" discourse of nationalism (Janmahmad 1988: 259-69; Inayatullah 1987: 35-36) taken into consideration so far reveals an intertwining of ideas and representations belonging both to the experience of European nationalism and to the Baluchi memory-archive; both to the discourse of European historical science and to the local representation of recent political history. This discourse flows, we may say, into what Ulf Hannerz has called geocultural imagination. In Hannerz's words, geocultural imagination would be "a matter of fairly large-scale mapmaking", a way of referring "to the distribution of things cultural, somehow cultural, over territories and their human populations" (Hannerz 2007).

At the same time the expression "geocultural imagination" is a way of "suggesting that [we are] focusing on the way we think geoculturally, about the world and its parts, and the main features of those parts."

"In anthropology, geocultural construction work and critique - he goes on to say - were early ingredients of the discipline in Europe as well as North America, in continental Kulturkreislehre as well as in the careful mapping of trait distributions to establish the culture areas of Native Americans."

Yet, continues Hannerz, "in those days, a century or so ago, these were mostly activities of the ivory tower, where scholars would argue over matters of conceptualization and categorization mostly with their peers. In more recent times, it seems to me that the geocultural imagination has become more volatile, occurring in both academic and public arenas and also crossing the boundaries between them more readily, and more ambiguously."

These geocultural representations are, according to Hannerz, "significant components in a transnational collective consciousness, a set of representations of the world which are circulated, received and debated in a world-wide web of social relationships, and which again stimulate further cultural production."

They are representations affecting broad strata of world society, thanks to the spread of literacy and, especially to the medium of television.

Geocultural imagination, during the 1990s, had its maximum propagators in a number of "organic intellectuals", the kind of people who refine and explicate the perspectives of a certain political class of which they are in some way members. For example, Huntington, Kagan, Fukuyama, to mention only the best-known, "served in Washington in one administration or another." The bestknown among these, Samuel Huntington, has linked his name to the geocultural image of a "clash of civilizations", where the reduction of culture to religion is a fundamental pillar of his argument (Huntington 1996). This image of the cultural dynamic is one of those which Clifford Geertz 
would readily have defined as typical of "politologists in a balloon" (Geertz 1999). In fact, whilst we have to recognise the extraordinary power of persuasion exerted by it in terms of geocultural imagination, we must also underline its poor analytical capacity at an ethnographic level.

There is no doubt that when the idea of a "Greater Baluchistan" was enounced in 1933, geocultural imagination was already present among the Baluchi nationalists themselves. We can, however, also note that the idea of a Greater Baluchistan changed according to specific political strategies and moments. It is in fact possible to note these changes by comparing the various versions of this idea that have succeeded one another in time. For the nationalists of 1933, "Greater Baluchistan" should have embraced, in addition to the Iranian and Indian (now Pakistani) Baluchistan, the Sindh, the region of Bahawalpur and the Dera Ghaza Khan and Ismail Khan areas. Strangely, Afghan Baluchistan was not mentioned (and thus not even indicated on the annexed map). The reason for this omission is that at the time Afghanistan was already a sanctuary and a potential ally of the Baluchi nationalists, as it was also to have been in the years 1970-80, thanks to the then pro-Soviet and anti-Pakistan government in Kabul. In the mid-twentieth century on the other hand, the idea of a Greater Baluchistan again included Afghan Baluchistan, whilst the northern region of Dera Ghazi Khan had disappeared - but only to return in the 1990s as a topic of debate. Set on the north east limits of what is considered the maximum point of expansion of the Baluch during the sixteenth century, this area became once again the focus of attention by the nationalists after the possibility of important uranium deposits had been suggested in the neighbourhood.

It can thus be noted that geocultural imagination - the representation of spaces "containing" dominant cultural forms - changed according to periods, but also above all to contingent political circumstances. It is largely a mental construction, whose "form" depends on discursive strategies "useful to the purpose" at differing times.

However, as we were saying, these geocultural representations are analytically ineffective, since they reduce the cultural complexity to a few "essential" traits. They are in fact promptly belied by practice.

I mentioned earlier the best-known case of geocultural imagination: that of the reduction of culture to religion, carried out by Huntington in his celebrated book of 1996. It is interesting therefore to see the place of religion in the Baluchi nationalist discourse and in the effective behaviour of those who share it. Baluchi nationalism is in fact a secular movement, having no organic connections with Sunnite religious circles.

\section{The "religious question"}

The Baluch are for the most part Sunnite Muslims, but a substantial minority are believers in Zikr, a form of worship dating to $16^{\text {th }}$ century that has references to Shiite Islam and is particularly widespread in the south of the country as well as among Baluch migrants in Sindh and in the Gulf area.

Still in the eighteenth century, almost the whole of the population of southern Baluchistan was of Zikri faith. Only then did this "confession" begin slowly to decline, so slowly that by the end of the nineteenth century the Anglo-British administrator-ethnographers, in recording their high number, were quick to consider them a veritable "tribe" (Baluchistan District Gazetteer, 1906).

The decline of Zikr towards the middle of the eighteenth century was a consequence of military intervention by the Khan of Kalat, which smashed the "separatism" of the lords (hakim) in the 
southern regions (who at the time were followers of Zikr) by conducting nothing short of a jihad against the "Zikri infidels". After the local lords, defeated and deprived of much of their autonomy, had been converted to Sunnite orthodoxy, the Zikri were left free to practise their worship. Although a part of the population with time did abandon Zikr, following the example of their local lords, the presence of this cult nevertheless remained strong in the region. In the mid-1990s the principal Zikri sanctuary, not far from the city of Turbat, was still attracting yearly, at the end of the Muslim month of Ramadan, some thirty thousand pilgrims from all corners of Pakistan.

Since the mid-eighteenth century there has been no further contrast between Zikri and Sunnites. Zikri, as recently as in the 1990s, still had no difficulty at all in proclaiming their religion and practising it throughout Baluchistan.

However, from the mid-1980s, Zikri have been the object of attacks, and not only verbal ones, by Sunnite mullahs (Ahmed 1987).

Having come from regions outside Baluchistan and organized expeditions of non-Baluchs into the south of the country, these mullahs, connected with the Koranic schools situated in the northern and eastern regions of Pakistan, attempted to raise the question of what they consider to be heresy. Their attempts however did not produce the results expected by the promoters of these "punitive expeditions".

The Sunnite Baluch in fact saw these raids led by "fanatical mullahs" (as they call them) as nothing more than one of the numerous plots woven by the government to foment disagreement among the Baluch themselves.

During the years of my research (1986-1994), the friction between orthodox non-Baluchs on the one hand, and Zikri and Sunnite Baluchs on the other, had several times risen to a considerable level of danger, to a point where even those in power locally (and who, according to the nationalists, were deeply compromised with central government), had openly declared themselves in favour of religious freedom and of the Zikris' right to practise their beliefs.

But what is the attitude of the nationalists towards the religious question? The idea of the mullahs' raids as the product of destabilization plans by the Islamabad government did not seem at that time to have serious foundations. But if one looks at the reasons given by Pakistani governments to justify the annexation of Baluchistan, it can be noted that the one adopted most frequently has been that of "religious unity" i.e. "purity" of the country. Pakistan means in fact the "Land of the Pure".

One should not be surprised therefore if nationalism regards incursions of fanatical mullahs as manoeuvres aimed to create a state of division and confusion among the Baluch.

If religious foundamentalism is recognized as an element of anti-Baluch policy, the nationalist argument shows a tolerance in matter of faith, and even a clear inclination towards secularism. And to the point where the holy war waged by the Khan of Kalat against the Zikri more than two centuries ago is considered a marginal episode, in keeping with the idea of the Khanate as a political precedent of historically largely achieved unity.

This is just one example of how, on a practical level, representations of a culturally homogeneous Baluchistan with no internal differentiations disappear altogether in terms of geocultural imagination, where again the propagandist element blots out all the others.

We must therefore concentrate on the socio-political context within which the nationalist discourse operates. 


\section{The social basis of nationalist movement}

In the light of the grand historico-cultural visions embraced by the Baluch nationalists, there exist in fact, within the latter, different attitudes to the "Baluchi question". There are not only differing political options, depending on one ideological choice rather than another (for example the contrast, in the 1980s, between Marxists and non-Marxists); there are also differences relating to the social history of the different areas of Baluchistan itself. One difference which, from this angle, seems to me very important is that between the north and the rest of Baluchistan. The North is by tradition the land of the great tribes and tribal leaders (sardàr). The south is on the other hand characterized by the presence of a heavily stratified agricultural society founded on the patron-client relationship (Fabietti 1992). This difference has repercussions on the type of relationship that exists between the Baluchi community and the state of Pakistan.

The tribes of the north interact with the external powers (now with the Pakistani state) through their traditional leaders. It is true that in the south too, the key exponents of this policy belong to the upper echelons of the hierarchy, but the morphology of local society makes the following of a prominent leader less stable and reliable than in the north.

In the north we find a structure of relationships that falls roughly into the category of "segmentary" societies. Every large "tribe", qowm, is composed of a series of lineages", khel, each with a sardàr of its own (Pehrson 1966: 17-18). From one of these khel comes the "tribal" sardàr, an office passed down by inheritance within a single lineage, and called, in fact, sardàr khel. The lineages making up a "tribe" are thought of as descending from a common ancestor, from whom, however, not all are "equidistant". Indeed the sardàr khel, that is to say the lineage to which the tribal chief belongs, is considered genealogically "closer" (i.e. descending in direct line) to the tribal ancestor.

In southern Baluchistan on the other hand, the khel system is absent, whilst the patron-client relationship prevails. This constitutes the foundation of a stratified society, in which individuals recognise their subordination to other individuals. The relationship of dependency that binds many individuals without means to a mastèr (literally "the biggest"), is certainly binding but is in some ways less "constrictive" than tribal affiliation. The relationship between client and master is in fact configured as one of dependency which can be interrupted by means of affiliation, by a client, to a new mastèr. The absence of "tribal" bonds therefore makes the following of a mastèr potentially more "unstable" than that of a sardàr and, above all, less "morally" pledged to his service. This could help to explain why the leading figures of Baluchi nationalism have been - with rare exceptions - tribal sardàrs, and why the armed conflict waged in the seventies was mainly provoked by the large tribes of the north bound to their sardàr (Harrison 1981; Redaelli 1996).

The particular position occupied by the sardàrs, which in the past allowed some of them to present themselves as champions of Baluchi independence, is however not without contradictory aspects. There are nationalists sardàrs who have been accused, both by the nationalists themselves and by the central government, of adopting a "conservative" attitude to the Baluchi question, allegedly determined by calculations of personal opportunity. ${ }^{6}$

\footnotetext{
${ }^{5}$ There exists in fact a grading in the "distance" of the various khels of the apical ("tribal") ancestor. This difference of distance is sometimes imputed by members of the society themselves to the fact that some khels, especially the more "distant" ones, are allegedly of a different tribal origin.

${ }^{6}$ Cases are cited of sardàrs who allegedly urged their tribes to refuse the building of roads and schools
} 
To consider the sardàrs conservatives in bad faith is perhaps a bit too simple (some have paid for their anti-government attitude with prison, exile and even death). However, this situation does testify, on the whole, to the contradiction that exists between aspirations to unity and autonomy on the one hand, and to "tribal particularism" on the other. The ambiguity of the sardàrs' attitude seems to be not so much the product of personal calculations as of the position that they occupy in the context of relations between Baluch and Pakistani central government. The sardàrs occupy a prominent position within a socio-politically "tribal" structure, seen by a part of nationalist thinking as an obstacle to the realization of its designs.

Baluchi nationalism thus seems to be marked by a twofold character, that of the tribes and that of Baluchi "modernist" educated people who consider the so called "tribalism" to be a force contrary to the achievement of the region's independence in a manner inspired by the idea of a Baluchi culture and "national" society. However much one may strive to promote in various ways an image of the Baluch people released from the tribal heritage, for example by affixing to personal documents not "tribal" names but very simply the wording "Baloch" as a "surname" - it is nevertheless true that anti-Pakistan mobilization has occurred to date mainly in the light of political choices - and not always clear ones, made by the sardàr (Harrison 1981; Titus 1990).

As in all phenomena definable as "nationalism", the appearance of national unity and identity in Baluchistan is not simply the effect of a demand from within local society. Rather, it is the result of an inner sentiment prompted by external forces. This external force coincides with a large number of factors. Firstly, the Pakistani state which tends, like any state, to impose its authority on the territories under its jurisdiction. Then there are the other states in the region, and the non-Asian powers that have at times exerted dramatic pressure on Baluchistan.

It would however be reductive to maintain that colonization or violence on the part of an outside power can, as such, spark a form of reaction self-proclaimed as nationalist. Baluchistan had been subjected for centuries, if not for thousands of years, to the pressure of foreign powers, but of course this fact had never until recently been the origin of anything that might be qualified as "nationalism".

With British and subsequently Pakistani rule, something however did change. Education reached Baluchistan and schools, though overcrowded and with ill-prepared teachers, were opened, with a University in Quetta, the capital of Baluchistan. As a consequence, thousands of young people have had access to information and professional qualifications that do not fit a society of pastoral herders and date palm growers. It is no coincidence that the two students' organizations, the Baluchistan Student Organization and a dissident part of it, have several thousand members and that, still more significantly, they represent the two most active political movements in Baluchistan.

It is true that some nationalists see the development of educational facilities and services by the Pakistan authorities as an attempt to favour certain classes and thus to break up the solidarity of the Baluch to the advantage of the government, besides being a quite insufficient remedy for the

on their territories, with the excuse that too rapid modernization would have had traumatic effects on the population. This kind of refusal has been interpreted by some nationalists as proof of bad faith on the part of the sardàrs, who, they allege, are afraid of loosing their privileges. These sardàrs reply to this accusation by upholding the idea of an autonomous Baluchistan whose population should be entitled to preserve its customs and institutions. 
growth of the region. But this development of educational structures has produced an entirely new situation. In it young Baluch aspire to find a place for themselves in a world quite different to that of the past generations. However they are frustrated in these aspirations, by a state that is unable to guarantee access to new conditions of life to all the official "ethnic groups" living on its territory. This is all the more true in the case of conditions which the presence of the state has contributed to create.

The presence of a state as such today, tends in fact to set the condition for a greater mobility of individuals and for increased communication between the different sectors of society.

In this sense those, like Gellner (1983), who consider nationalism to be a product of "modernity", are right.

So it seems that nationalism emerges where, with the widening of a situation of difference perceived at the ethnic and cultural level, a gap arises between the system of expectations and the possibility of actually fulfilling those expectations.

\section{The re-invention of tradition and the "traffic" of cultures}

Any reflection on a cultural otherness brings into play what Roy Wagner (1982) qualified as a reinvention of its own culture. Those observing others, and reflecting on others, make use of analogies and metaphors inferred from their own cultural codes. Thus they end up, in a way, by "objectifying" their own culture, so as to make it appear in a different light to that in which it had been presented to them previously: they "reinvent" it. This does not concern only the ethnographer. For his or her interlocutors, too, must understand the people they are dealing with, and to do that they too must resort to models and metaphors inferred from their own cultural repertoire. They too, like the ethnographer, arrive at an objectification of their own culture, hence its reinvention.

In this kind of "primary scene" presented to us by Wagner - the ethnographic encounter - the objectification of one's own culture is translated into the "incorporation" of concepts and meanings of other people's cultures into one's own. This is what happens on a reduced scale, and on an intersubjective level, in the ethnographic encounter. But it is also what happens in the "contact between cultures", in a period in which history seems to "accelerate", in which the transfer of technologies, the adoption of a language of exchange (as for example English), the circulation of information, the market and the media, enable peoples to "communicate" with one another. By taking up themes of western scientific thinking, and ideologies originating from the same cultural source, the discourse on Baluchi nationalism manages, by dipping into the local memory-archive, to reinvent tradition, and hence to invent a new one.

But this process does not occur within an "equal" situation. The circulation of meanings, this kind of "traffic of cultures", never happens in a "neutral space" characterised by equality of the interlocutors, but rather within a general picture characterised by specific relationships of force. As Talal Asad (1986) pointed out, these relationships of force can also be translated, besides everything that we know very well, into a hegemony of "languages" by one culture over another. Serving the "reinvention" of an identity being formed, and as such threatened, as is in fact that of the Baluch, the western languages of political science, linguistics and historiography, like certain influences of European nationalist tradition exercise, in the context examined, an action of dominion (in the University of Baluchistan, to my great surprise, I came across a historian interested in the Italian 
"Risorgimento"). This does not mean that the resumption and adoption, by Baluchi nationalists, of European-sourced ideas, should be construed as an example of the direct dominion of western culture over the local one. Rather, it means that local culture is learning to think itself also through those ideas and those representations. From this point of view, the themes of Baluchi nationalism, and the modes of their articulation into a discourse with claims to coherency, constitute an example of what can be intended, today, by "specific historical relations of dominance and dialogue" (Clifford 1987: 23) between different cultures; in a period in which, to borrow an expression used by Christopher Hann (Hann 1994), "history accelerates".

Ugo Fabietti is Professor of Cultural Anthropology at the University of Milano Bicocca. Author of many books and articles dealing with pastoral nomadism, ethnograhic methodology, ethnicity, epistemology and history of anthropology. 


\section{References}

Ahmad Yar Khan Baloch. 1975. Inside Baluchistan, Karachi: Royal Book Company.

Ahmed, A. S. 1987. Islamic Fundamentalism, Sufism and Ethnicity in Pakistan: a Case-Study from Baluchistan, Journal of Central Asia 10/1: 37-61.

Akbar, I. 1989. The Heroin Coast, The Herald, Karachi, October.

Anderson, B. 1983. Imagined Communities. Reflections on the Origin and Spread of Nationalism, London: Verso.

Asad, T. 1986. The Concept of Cultural Translation in British Social Anthropology, in: Clifford, J. and Marcus, G.E. (eds.), Writing Culture. The Poetics and Politics of Anthropology. Berkeley: University of California Press 1986.

Assmann, A. 1999. Erinnerungsräume. Formen und Wandlungen des kulturellen Gedächtnisses (It. Tran. Ricordare. Forme e mutamenti della memoria culturale, Bologna, Il Mulino 2002).

Armstrong, J. 1982. Nations before Nationalism. Chapel Hill: University of N. Carolina Press.

Baluchistan District Gazetteer 1906 (Vol. VII, Makran). Bombay: The Times Press.

Barth, F. 1969. Pathan Identity and its Maintenance, in: Barth, F. (ed.) Ethnic Groups and Boundaries. Boston: Little, Brown and Co.

Bray, D. 1977. The Brahui Language, 2 vols. Quetta: Brahui Academy (Or. Ed. 1907).

Clifford, J. 1987. The Predicament of Culture. Cambridge: Mass. Harvard University Press.

Dames, L. M. 1904. An Historical and Ethnological Sketch of Balochi Race. London: Royal Asiatic Society.

Dames, L. M. 1907. Popular Poetry of the Baloches. London: Folklore Society.

Fabietti, U. 1992. Power relations in Southern Baluchistan. A comparison of three ethnographic cases, Ethnology 32: 89-102.

Fabietti, U. 1996a. Water-sharing systems in southern Baluchistan. Between Synchronisation and Desynchronisation, Social Science Information 4: 721-34.

Fabietti, U. 1996b. Equality versus Hierarchy: Conceptualizing Change in Southern Baluchistan, in: Titus, P. (ed.), Marginality and Modernity. Ethnicity and Change in Post-Colonial Baluchistan, Karachi: Oxford University Press, 3-27.

Fabietti, U. 1997. Etnografia della frontiera. Antropologia e storia in Baluchistan, Roma, Meltemi.

Foucault, M. 1969. L'archéologie du savoir. Paris: Gallimard.

Geertz, C. 1999. Mondo globale, mondi locali. Bologna: Il Mulino.

Gellner, E. 1983. Nations and Nationalism. Oxford: Blackwell.

Gingrich, A. and M. Banks (eds.). 2006. Neo-Nationalism in Europe and Beyond. Perspectives from Social Anthropology. New York: Berghahn.

Hann, C.M. (ed.). 1994. When History accelerates. London: The Athlone Press.

Hannerz U. The Geocultural Imagination: Scenarios and Storylines. Paper read at a seminar held in Milano Bicocca University on March 20, 2007.

Harrison, S. S. 1981. In the Afghanistan's Shadow. Baluch Nationalism and Soviet Temptations. New York: Carnegie Endowment for International Peace. 
Hobsbawm E. and Ranger T. (eds.). 1983. The Invention of Tradition. Cambridge: Cambridge University Press.

Huntington, S. P. 1996. The Clash of Civilizations and the Remaking of World Order. New York: Simon and Schuster.

Inayatullah Baloch. 1987. The Problem of “Greater Baluchistan”. A study of Baluchi Nationalism, Stuttgart: Franz Steiner Verlag.

Janmahmad (J. Baloch). 1988. Essays on Baloch National Struggle in Pakistan. Quetta: Gosha-e-Adab.

Pastner, S. and C. 1972. Agriculture Kinship and Politics in Southern Baluchistan, Man 7/1: 12836.

Pehrson, R.N. 1966. The Social Organization of the Marri Baluch. Compiled and analyzed from bis notes by F. Barth. Chicago: Aldine.

Redaelli, R. 1996. Il Khanato di Kalat. Inghilterra, Russia e Persia: questioni di frontiera (XIX-XX secolo). Milano: I.S.U.-Università Cattolica.

Renfrew, C. 1987. Archaeology and Language. The Puzzle of Indo-European Origins. London: J. Cape.

Sardar Khan Baluch, M. 1977-1984. Literary History of the Baluchis, 2 vols. Quetta: Balochi Academy.

Smith, A.D. 1986. The Ethnic Origins of Nations. Oxford: Blackwell.

Swidler, N. 1979. Brahui Political Organization and the National State, in: Embree, A.T. (ed.), Pakistan's Western Borderlands. Karachi: Royal Book Company.

Wagner, R. 1982. The Invention of Culture. Chicago: Aldine. 